FOLIA SCANDINAVICA VOL. 20 POZNAŃ 2016 DOI: 10.1515/fsp-2016-0041

DE DE GRUYTER OPEN

PRESSto.

\section{OVERSÆTTELSESSTRATEGIER AF RETNINGSADVERBIET UD I POLSKE OVERSÆTTELSER AF H.C. ANDERSENS EVENTYR \& HISTORIER}

\author{
MICHAŁ SMUŁCZYŃSKI \\ Univeristy of Wroctaw
}

ABSTRACT. The article is an investigation into strategies applied when translating Danish sentences with the directional adverb $u d$ into Polish. The analyzed material consists of three different translations of a selection of H.C. Andersen's fairytales into Polish, i.e. Cecylia Niewiadomska's (1908), Stefania Beylin and Jarosław Iwaszkiewicz's (1975) and Bogusława Sochańska's (2006). The analysis is mainly focused on the Polish equivalents of Danish sentences with the directional adverb $u d$. However, since only Sochańska's translation is a direct translation from Danish into Polish (the remaining ones are translations via German) the article's analytical part also includes a comparison of strategies applied by the individual translators. Lastly, some comments are made with regards to the semantic status of the Danish directional adverb $u d$ and its Polish equivalents.

\section{INDLEDNING}

Det følgende bidrag er en oversættelsesanalyse af udvalgte eventyr af H.C. Andersen, med hensyn til oversættelsesstrategier af retningsadverbium $u d$ med fokus på de (mulige) sproglige instrumenter, som $u d$ kan gengives med på polsk. Det andet formål med bidraget er at beskrive fænomenet retningsadverbium i dansk.

Analysen er baseret på 3 oversættelser af 6 udvalgte eventyr til polsk Cecylia Niewiadomskas (1908), Stefania Beylin og Jarosław Iwaszkiewicz' (1975) og Bogusława Sochańskas (2006). Sochańskas oversættelse er den mest omfattende, men det vigtigste er, at Sochańska har oversat eventyrene direkte fra dansk til polsk, mens både Beylin/Iwaszkiewicz og Niewiadomska støttede sig 
til en tysk oversættelse. Derfor vil jeg ikke kun koncentrere mig om selve oversættelsesstrategierne af retningsadverbiet $u d$, men også sammenligne de enkelte oversætteres strategier med hinanden.

\section{RETNINGSADVERBIER I DANSK}

I ethvert sprog findes der bestemte redskaber til at udtrykke bevægelsesretninger. I dansk bruger man i denne funktion retningsadverbier, der spiller en rigtig stor rolle i dette skandinaviske sprog. If $\varnothing$ lge Harder et al. (1996:161) er der 12 retningsadverbier i dansk ${ }^{1}$. I KorpusDK ligger $u d$ med 85969 forekomster på andenpladsen blandt de hyppigst brugte retningsadverbier, jf. nedenfor:

\begin{tabular}{llc}
\hline & Retningsadverbium & Antal forekomster \\
\hline 1. & op & 98964 \\
\hline 2. & ud & $\mathbf{8 5 9 6 9}$ \\
\hline 3. & ned & 45214 \\
\hline 4. & ind & 39769 \\
\hline 5. & tilbage & 39461 \\
\hline 6. & frem & 27544 \\
\hline 7. & af & 27444 \\
\hline 8. & hen & 21079 \\
\hline 9. & hjem & 17731 \\
\hline 10. & over & 17532 \\
\hline 11. & om & 12405 \\
\hline 12. & bort & 3937 \\
\hline
\end{tabular}

(Tab. 1) Danske retnigsadverbiers forekomster i KorpusDK

Bortset fra tilbage, af og bort har hvert retningsadverbium tre former: den dynamiske $\varnothing$-form, den statiske e-form og den processuelle form med suffiks, f. eks. -ad/-efter/-pål-til (jf. Harder et al., 1996:160 ff.; Hovmark, 2007:60 ff.):

${ }^{1}$ Både Hansen/Heltoft (2011, I:216) og Rajnik (2014:213 ff.) angiver dog, at der er 10 retningsadverbier. De anser hverken tilbage eller af som retningsadverbier. 


\begin{tabular}{lll}
\hline$\varnothing$-formen & e-formen & Formen med suffiks \\
\hline ud & ude & udad \\
\hline ind & inde & indad \\
\hline op & oppe & opad \\
\hline ned & nede & nedad \\
\hline tilbage & tilbage & - \\
\hline frem & fremme & fremad \\
\hline af & af & - \\
\hline hen & henne & henad \\
\hline hjem & hjemme & hjemad \\
\hline over & ovre & overad \\
\hline om & omme & omad \\
\hline bort & borte & - \\
\hline
\end{tabular}

(Tab. 2) Danske retnigsadverbiers former

Ifølge Hovmark har alle formerne en fælles telisk-dynamisk grundstruktur ${ }^{2}$. Forskellen ligger i, hvordan grundstrukturen bliver kodet af enkelte retningsadverbiumstyper. Dette kan skildres grafisk, hvor den grå farve bruges for at markere, hvad de enkelte retningsadverbiumstyper profilerer, dvs. "en fuld telisk bevægelse" (Ø-formen), "målet i en forudgående, fiktiv eller forudsat bevægelse" (e-formen) eller en bevægelse som en uafsluttet proces (jf. Hovmark, 2007:61 ff.):

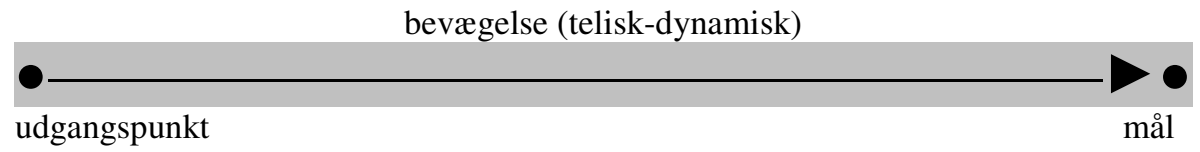

(Fig. 1) Dynamiske retningsadverbier

bevægelse (telisk-dynamisk)

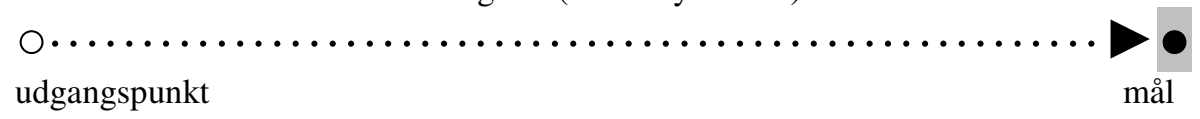

(Fig. 2) Statiske retningsadverbier

${ }^{2}$ Udgangspunktet for alle formerne er en telisk bevægelse i en dynamisk Motion event, hvor hverken udgangspunktet eller målet er specifikt (jf. Hovmark, 2007:61 ff.). 


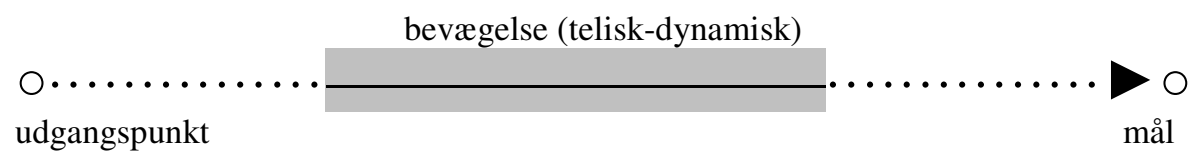

(Fig. 3) Procesuelle retningsadverbier

Et retningsadverbium fungerer i en dansk sætning som prædikativ (jf. Hansen og Heltoft, $2011 \mathrm{I}$ :217). Men retningsadverbiets rigtige funktion kan ikke vises, hvis vi ser et dansk verbum som monolit, altså som en semantisk helhed. Et verbums betydning bliver ofte delt af den danske syntaks i to konstituenter, nemlig et HOVEDPRÆDIKAT og et BIPRÆDIKAT (eng. host predicate og copredicate, jf. Harder et al., 1996:160 ff.). Den gensidige kooperation mellem de to komponenter er af stor betydning for sætningsbetydningen i det danske sprog (ibid.).

Retningsadverbiernes rolle bestemmes af sammenhængen mellem subjekt og adverbial, der informerer om retning i forhold til stedet. Harder et al. (1996:160 ff.) konstaterer, at retningsadverbier ofte udtrykker en bevægelse i forhold til en subjektiv, forudsat position. Der er derfor tale om lokalisation(sændring) i forhold til noget, oftest til subjektet, jf. $(1)^{3}$. Retningsadverbiets udeladelse ville i den slags tilfælde kræve en speciel kontekst, hvor det subjektive forhold mellem subjektets og en anden genstands placering ikke er relevant (ibid.), jf. (2):

(1) a. Kaffekanden står ude i køkkenet.

b. Telefonen står inde i stuen.

(2) a. Kaffekanden står i køkkenet.

b. Telefonen står i stuen.

Ofte beskrives bevægelsen i en bredere geografisk dimension også i en subjektiv relation til subjektets placering. (3) kan derfor forstås som udtryk for et dansk perspektiv, mens (4) kan betragtes som mere neutral (jf. Harder et al., 1996:163):

(3) Vi rejste op til Nordnorge.

(4) Vi rejste til Nordnorge.

Der er også tilfælde, hvor afstanden mellem subjektet og objektet er kæmpestor. I den slags tilfælde udelader man typisk adverbiet, medmindre den talende mener, at den genstand, der er tale om, alligevel står i en eller andet relation til ham/hende, jf. Harder et al. (1996:163):

(5) Der er kanaler (ude) på Mars.

(6) Raketten flyver (ud) til Mars.

${ }^{3}$ Eksemplerne (1a) og (2a) samt (3) - (8) stammer fra Harder et al. (1996:163 ff.). 
Bevægelsesverber udgør et specielt tilfælde. Når de forekommer sammen med et adverbial, som beskriver både bevægelsens retning og mål, gør udeladelsen af retningsadverbiet ikke sætningen grammatisk ukorrekt, men den påvirker i høj grad sætningens semantik. Der er nemlig en stor betydningsforskel mellem (7) og (8):

(7) Gå hen til lægen!

(8) Gå til lægen!

Uden retningsadverbiet hen har (8) en institutionel betydning, dvs. det drejer sig ikke om en konkret læge, mens brugen af retningsadverbiet understreger fokus på bevægelsen/ lokalisationsændringen (jf. Harder et al., 1996:170).

Der findes også tilfælde, hvor retningsadverbier ikke fungerer som biprædikater, men sammen med verbet konstituerer en idiomatiseret semantisk enhed. Så kan et retningsadverbium enten delvist beholde sin betydning og snarere henvise til en bestemt handlingsmåde end til bevægelsens retning, som fx i smide $u d$, eller miste den fuldstændigt, som fx i høre op og stikke af (jf. Harder et al., 1996:164 f.). I dette bidrag bliver der kun taget højde for de anvendelser af retningsadverbiet $u d$, hvor det fungerer som biprædikat.

At oversætte retningsadverbier kan potentielt forvolde store problemer. Nogle af dem, som fx hen/henne, anses nemlig for uoversættelige (Harder et al., 1996:164). Denne adverbiumstype forekommer fx ikke i det polske sprog, hvilket $g ø r$ en direkte oversættelse til polsk umulig. For at gengive adverbiets betydning må man derfor gribe til andre oversættelsesstrategier.

\section{ANALYSE AF OVERSÆTTELSESSTRATEGIERNE}

\subsection{DET UNDERSØGTE MATERIALE}

Analysen omfatter 35 danske sætninger med retningsadverbiet $u d$ og 3 oversættelser af hver af sætningerne til polsk (jf. Appendiks), hvilket potentielt giver 105 forskellige oversættelser/oversættelsesstrategier. De danske sætninger stammer alle sammen fra eventyrene Snedronningen, Den lille havfrue, Tommelise, Den lille Idas blomster, Rejsekammeraten og Den grimme aelling (jf. Andersen, 2005), som er blevet valgt som undersøgelsesmateriale, fordi de hører til blandt Andersens mest populære eventyr. Sætningerne er blevet valgt således, at alle forekomster af retningsadverbiet $u d$ i det analyserede materiale er tilfælde, hvor $u d$ fungerer som biprædikat (jf. kapitel 2).

I den følgende omtale af oversættelsesstrategierne samt i selve Appendikset er Niewiadomskas oversættelser markeret med symbolet [N], Beylins og Iwaszkiewiczs med symbolet [B/I] og Sochańskas med symbolet [S]. Eksemplerne har numre fra [1] til [35]. 


\subsection{OVERSIGT OVER DE ANVENDTE OVERSÆTTELSESSTRATEGIER}

I tabellen nedenfor findes en oversigt over oversættelsesstrategier af retningsadverbiet $u d$, der er blevet anvendt i det undersøgte materiale. Tabellen er delt efter oversættere og deres strategier.

\begin{tabular}{|c|c|c|c|}
\hline \multirow{2}{*}{ Eksempel } & \multicolumn{3}{|c|}{ Oversættelsesstrategi } \\
\hline & Niewiadomska & Beylin/Iwaszkiewicz & Sochańska \\
\hline$[1],[2],[3],[4]$ & \multicolumn{3}{|c|}{$w y-$} \\
\hline [5] & verbum uden prafiks & Verbum uden prafiks & $w-$ \\
\hline$[6]$ & udeladelse & $n a-$ & verbum uden prafiks \\
\hline$[7]$ & \multicolumn{2}{|c|}{$w y-$} & $O-$ \\
\hline$[8]$ & udeladelse & $w y-$ & prze- \\
\hline [9] & \multicolumn{3}{|c|}{$w y-$} \\
\hline$[10]$ & \multicolumn{3}{|c|}{ od- } \\
\hline$[11]$ & od- & od- & verbum uden prafiks \\
\hline$[12]$ & afvigelse fra originalen & \multicolumn{2}{|r|}{$w y-$} \\
\hline$[13]$ & afvigelse fra originalen & \multicolumn{2}{|c|}{ wy- } \\
\hline [14] & $p o-$ & pod- & po- \\
\hline$[15]$ & afvigelse fra originalen & \multicolumn{2}{|c|}{ pod- } \\
\hline [16] & afvigelse fra originalen & \multicolumn{2}{|c|}{ wy- } \\
\hline [17] & afvigelse fra originalen & \multicolumn{2}{|c|}{$w y-$} \\
\hline$[18]$ & $w z_{-}^{-}$ & \multicolumn{2}{|c|}{ po- } \\
\hline [19] & \multicolumn{3}{|c|}{ przy- } \\
\hline [20], [21], [22] & \multicolumn{3}{|c|}{$w y-$} \\
\hline [23] & \multicolumn{3}{|c|}{$z a-$} \\
\hline$[24],[25]$ & \multicolumn{3}{|c|}{ po- } \\
\hline$[26]$ & $w y-$ & verbum uden prafiks & $w y-$ \\
\hline [27] & afvigelse fra originalen & \multicolumn{2}{|l|}{$w y$} \\
\hline$[28]$ & \multicolumn{3}{|c|}{ verbum uden prafiks } \\
\hline [29] & $d o-$ & przy- & $d o-$ \\
\hline [30] & \multicolumn{3}{|c|}{$w y-$} \\
\hline [31], [32] & \multicolumn{3}{|c|}{ roz- } \\
\hline [33] & po- & \multicolumn{2}{|l|}{$s-$} \\
\hline$[34],[35]$ & \multicolumn{3}{|c|}{ verbum uden prafiks } \\
\hline
\end{tabular}

(Tab. 3) Oversigt over de anvendte oversattelsesstrategier 
Af ovenstående fremgår det, at den oftest brugte strategi for at gengive retningsadverbiet $u d \mathrm{i}$ de analyserede oversættelser er præfigering (83 forekomster). I det analyserede materiale gengives $u d$ ved hjælp af 14 forskellige præfikser (do-, na-, o-, od-, po-, pod-, prze-, przy-, roz-, s-, w-, wy-, wz- og za-). Den næsthyppigst brugte oversættelsesstrategi er at anvende et verbum uden præfiks. Der er også nogle tilfælde, hvor den originale sætning er blevet udeladt, og hvor oversættelsen afviger betydeligt fra originalen. Nedenfor præsenteres en oversigt over, hvor ofte de enkelte oversættere har anvendt de forskellige oversættelsesstrategier i det analyserede materiale:

\begin{tabular}{|c|c|c|c|c|}
\hline \multirow{2}{*}{ Oversættelsesstrategi } & \multicolumn{3}{|c|}{ Antal anvendelser } & \multirow{2}{*}{ I alt } \\
\hline & Niewiadomska & Beylin/Iwaszkiewicz & Sochańska & \\
\hline do- & 1 & - & 1 & 2 \\
\hline$n a-$ & - & 1 & - & 1 \\
\hline$o-$ & - & - & 1 & 1 \\
\hline$o d-$ & 2 & 2 & 1 & 5 \\
\hline po- & 4 & 3 & 4 & 11 \\
\hline pod- & - & 2 & 1 & 3 \\
\hline prze- & - & - & 1 & 1 \\
\hline przy- & 1 & 2 & 1 & 4 \\
\hline roz- & 2 & 2 & 2 & 6 \\
\hline$s-$ & - & 1 & 1 & 2 \\
\hline$w-$ & - & - & 1 & 1 \\
\hline$w y-$ & 11 & 16 & 15 & 42 \\
\hline$w z-$ & 1 & - & - & 1 \\
\hline$z a-$ & 1 & 1 & 1 & 3 \\
\hline verbum uden prafiks & 4 & 5 & 5 & 14 \\
\hline udeladelse & 2 & - & - & 2 \\
\hline afvigelse fra originalen & 6 & - & - & 6 \\
\hline
\end{tabular}

(Tab. 4) Antallet af de enkelte oversattelsesstrategiers forekomster hos de enkelte oversattere

Ud fra dataene i tabel 4 kan man se, at anvendelsen af et verbum med præfikset $w y$ - er den oftest anvendte oversættelsesstrategi - $40 \%$ af alle oversættelserne i det undersøgte materiale indeholder verber med dette præfiks. Dette er ikke overraskende, da både $u d$ og $w y$ - bruges i dansk og polsk for at markere hhv. bevægelsesretningen "bort fra et nuværende eller hidtidigt opholdssted og hen til en position udenfor" (DDO) og "indefra [og] udad" (SJP, min oversættelse). Po- er med 11 eksempler det andet oftest forekommende præfiks. Præfikserne 
do-, od-, pod-, przy-, roz- og za- har alle mellem 2 og 6 forekomster, mens hvert af præfikserne $n a-, o-$, prze-, $w$ - og $w z-$ kun forekommer en enkelt gang.

Bemærkelsesværdigt er også antallet af eksempler, hvor oversætterne har brugt bevægelsesverber uden præfiks. Med 14 forekomster ligger denne strategi på andenpladsen blandt de hyppigst anvendte i det undersøgte eksempler. I [28] og [35] blev kaste ud oversat til rzucać af alle oversætterne. Det samme har Sochańska i [5] oversat til wrzucać, mens Niewiadomska og Beylin/Iwaszkiewicz har valgt at anvende præfikset od- i eksempel [11]. Wrzucać er et meget interessant eksempel, fordi det polske præfiks $w$ - ofte har den betydning, at bevægelsen er rettet indad, mens $u d$ jo har den helt modsatte betydning.

De $\varnothing$ vrige strategier, der er blevet anvendt i de undersøgte eksempler, er udeladelse og afvigelse fra originalen (hhv. 2 og 6 forekomster).

\subsection{SAMMENLIGNING AF OVERSÆTTELSESSTRATEGIERNE HOS DE ENKELTE OVERSÆTTERE}

Forskellene mellem oversættelsesstrategier anvendt af de enkelte oversættere i de undersøgte eksempler beror oftest på, at de enkelte oversættere har anvendt verber med forskellige præfikser. Det vedrører eksemplerne [6], [8], [14], [18], [26], [29] og [33]. Der er til gengæld kun et eksempel ([6]), hvor oversætterne har brugt 3 forskellige strategier.

Mærkværdigvis er det Niewiadomska, hvis oversættelsesstrategier oftest adskiller sig fra de andre oversætteres. Selvom Beylin/Iwaszkiewicz har, ligesom Niewiadomska, oversat eventyrene fra tysk, er deres oversættelser af sætningerne med retningsadverbiet $u d$ næsten altid de samme som hos Sochańska (jf. [12], [13], [15]-[18], [27] og [33]). Det skal også tilføjes, at forskellen i oversættelsesstrategierne mellem Niewiadomska og de andre oversættere er større end mellem Sochańska og de øvrige oversættere. Derudover er der i alt 8 eksempler, hvor Niewiadomska enten har udeladt et stykke af originalteksten (jf. [6] og [8]) eller har modificeret teksten så meget, at hendes oversættelse afviger betydeligt fra originalen (jf. [12], [13], [15], [16], [17] og [27]).

\section{SEMANTISK STATUS AF UD OG DETS ÆKVIVALENTER}

I alle de analyserede eksempler fungerer $u d$ som biprædikat, og i alle danske eksempler har dette retningsadverbium den samme betydning - det er nemlig med til at betegne bevægelsen "bort [...] og hen til en position udenfor" (jf. DDO).

Retningsadverbiet $u d$ og de anvendte polske præfikser har den semantiske egenskab tilfælles, at de er med til at præcisere rumlige relationer, ikke mindst bevægelsesretningen. Blandt de anvendte polske præfikser synes wy-at ligge semantisk set tættest på det danske retningsadverbium $u d$.

I de analyserede polske oversættelser er det som sagt oftest verber med præfikser, som bruges ved gengivelsen af konstruktioner med retningsadverbiet 
ud. Ifølge Gruszczyński og Bralczyk (2002:22) har polske grammatikere det standpunkt, at perfektive verber oftest dannes ved hjælp af præfigering, fx czytać $\rightarrow$ przeczytać. I de analyserede oversættelser er de anvendte polske verber oftest perfektive, som fx wyjść, wyciagnać, odptynać, rozpostrzeć, sfrunać. Det skal dog understreges, at der er mange polske verber med præfikser, som fatkisk er imperfektive (jf. Gruszczyński og Bralczyk 2002:23). Sådanne eksempler forekommer også i det analyserede materiale, fx przechyla się i [8], wychodziła i [13] og [17], wymykała się i [16], przychodzi i [19]. Anvendelsen af et polsk verbum med præfiks er således ikke nogen garanti for, at den pågældende polske sætning får en samlet perfektiv betydning, lige som det ikke altid er tilfældet, at en dansk sætning med retningsadverbiet $u d$ overordnet set er perfektiv ${ }^{4}$.

\section{OPSUMMERING}

Formålet med dette bidrag har været at undersøge oversættelsesstrategier brugt ved gengivelse af danske sætninger med retningsadverbiet $u d$ på polsk. I det analyserede materiale, som bestod af tre forskellige oversættelser af udvalgte eventyr af H.C. Andersen, har oversætterne overordnet set brugt fire forskellige oversættelsesstrategier. Anvendelsen af verber med præfikser viste sig at være den hyppigst anvendte strategi. Blandt de øvrige oversættelsesstrategier er anvendelse af verber uden præfiks, udeladelser og afvigelser fra originalteksten. De to sidstnævnte strategier findes kun i Cecylia Niewiadomskas oversættelser. Anvendelsen af verber med forskellige præfikser var i фvrigt den oftest forekommende forskel mellem de enkelte oversætteres strategier, men det er også værd at bemærke, at i 18 tilfælde valgte alle oversættere at bruge det samme præfiks.

Den semantiske status af retningsadverbiet $u d$ og dets ækvivalenter er blevet omtalt i forhold til rumlige forhold og aspekt. Der synes at være en sammenhæng mellem den betydning, $u d$ og de tilsvarende polske præfikser bærer, hvad angår rumlige forhold. Man kan dog ikke konstatere, at $u d$ og de tilsvarende polske præfikser har samme status som aspektmarkører, da aspekt ikke er en rent verbal kategori i dansk.

Danske retningsadverbier og deres ækvivalenter er i hvert fald et interessant forskningsemne. Man kunne fx prøve at undersøge, om Harder et. al (1996) har ret i, at hen/henne/henad er uoversættelige, eller hvilket element af en sætning, der styrer den subjektive retningsangivelse.

\section{MATERIALE}

Andersen, H., C. (2005). Eventyr \& historier. Falun: Forlaget Sesam.

Andersen, H.C. (1908). Baśnie. Oversat af C. Niewiadomska. Hentet fra www.wolnelektury.pl/ (29.08.2016)

\footnotetext{
${ }^{4}$ I dansk afhænger perfektivitet/imperfektivitet af flere faktorer og kan ofte først identificeres på frase- eller sætningsniveau (jf. Sobkowiak, 2009).
} 
Andersen, H.C. (1975). Baśnie. Oversat af S. Beylin, J. Iwaszkiewicz. Warszawa: Państwowy Instytut Wydawniczy.

Andersen, H.,C. (2006). Baśnie i opowieści (Bind 1-3). Oversat af B. Sochańska. Poznań: Media Rodzina.

\section{LITTERATURHENVISNINGER}

Gruszczyński, W., Bralczyk, J. (2002). Stownik gramatyki języka polskiego. Warszawa: WSiP.

Hansen, E., Heltoft, L. (2011). Grammatik over det Danske Sprog. Bind I-III Odense: Syddansk Universitetsforlag

Harder P. (et al.). (1996). Danish directional adverbs. Content syntax and complex predicates. A case for host and co-predicates. Studies in Language Companion Series 29, 159-199.

Hovmark, H. (2007). Danske retningsadverbier og rumlig orientering. (phd-afhandling). Hentet fra: nfi.ku.dk/publikationer/phd-afhandlinger/henrikhovmarkphdafhandling.pdf (29.09.2016)

Rajnik, E. (2014). Podstawy gramatyki języka duńskiego z ćwiczeniami. Poznań: Wydawnictwo Naukowe UAM.

Sobkowiak, M. (2009). Perfektivitet og imperfektivitet $i$ dansk og polsk - et kontrastivt studium i aspekt og aktionsart. (phd-afhandling) Hentet fra https://repozytorium.amu.edu.pl/handle/10593/1082 (29.09.2016)

\section{INTERNETKILDER}

DDO = Den Danske Ordbog. http://ordnet.dk/ddo. [29.08.2016]

KorpusDK. ordnet.dk/korpusdk [29.08.2016]

SJP = Słownik języka polskiego PWN. http://sjp.pwn.pl [29.08.2016]

\section{APPENDIKS}

\section{Eksempler fra Snedronningen}

[1] Gerda råbte endnu højere, og så kom ud af huset en gammel, gammel kone (...) (Andersen, 2005:274)

Wtem drzwi domku się otworzyły i wyszla z niego zgarbiona staruszka (...) (Andersen, 1908:6) [N]

(...) Wtedy z domku wyszła stara, stara kobieta (...) (Andersen, 1975, Bind 1:170) [B/I]

(...) Z domu wyszła bardzo, bardzo stara kobieta (...) (Andersen, 2006, Bind 1:306) [S]

[2] Det er guld! Det er guld! råbte de, styrtede frem, tog fat i hestene, slog de små jockeyer, kusken og tjenerne ihjel, og trak nu den lille Gerda ud af vognen. (Andersen, 2005:284)

- Złoto! Złoto! - krzyczeli i rzucili się na karetę, uchwycili konia za cugle, pozabijali służbę i wyciągnęli na drogę przerażoną Gerdę. (Andersen, 1908:10) [N]

- Złoto, złoto! - Wołali, pchali się naprzód, schwycili konie za uzdy, zabili małych forysiów, stangreta

i służących i wyciągnęli małą Gerdę z karety. (Andersen, 1975, Bind 1:177) [B/I]

- To złoto, złoto! - Zawołali, wyskoczyli z lasu, schwycili konie, zabili małych forysiów, woźnicę i służących, a na koniec wyciągnęli z karety Gerdę. (Andersen, 2006, Bind 1:316) [S]

[3] (...) så trak hun sin blanke kniv ud og den skinnede, så at det var grueligt. (Andersen, 2005:284)

Wyciągnęła zza pasa wielki nóż błyszczący (...) (Andersen, 1908:10) [N]

I wyciągnęła nóż, który błysnął tak, że aż ciarki po ciele przeszły. (Andersen, 1975, Bind 1:177) [B/I]

- I wyciągnęla błyszczący nóż, który lśnił, że aż strach. (Andersen, 2006, Bind 1:316) [S] 
[4] Og Gerda strakte hænderne, med de store bælgvanter, ud mod røverpigen og sagde farvel (...) (Andersen, 2005:287)

Gerda na pożegnanie wyciągnęła do niej małe rączki w ogromnych rękawicach (...) (Andersen, 1908:12) [N]

A Gerda wyciągnęla ręce w wielkich rękawicach do małej dziewczynki rozbójników (...) (Andersen, 1975, Bind 1:179) [B/I]

A Gerda wyciągnęła do niej ręce w ogromnych rękawicach (...) (Andersen, 2006, Bind $1: 319)[S]$

[5] (...) da tog hun sine røde sko, det kæreste hun havde, og kastede dem begge to ud i floden. (Andersen, 2005:273)

Więc co prędzej zdjęła buciki, śliczne, ukochane, czerwone buciki i rzuciła je w wodę. (Andersen, 1908:6) [N]

(...) Wtedy zdjęła swoje czerwone trzewiki, to, co miała najmilszego, i rzuciła je do rzeki (...) (Andersen, 1975, Bind 1:170) [B/I]

(...) Zdjęła swoje czerwone buciki, najukochańsze ze wszystkich, jakie miała, i wrzuciła je do rzeki (...) (Andersen, 2006, Bind 1:305) [S]

[6] Hun hælder vand af tepotten ud på et stykke tøj, hun holder, det er snørelivet. (Andersen, 2005:278)

Z imbryczka do herbaty nalewa wody na gorsecik, który trzyma w ręku. (Andersen, 1975, Bind $1: 173)[\mathrm{B} / \mathrm{I}]$

Leje z czajniczka wodę na jakieś ubranie, które trzyma w ręku, to gorset. (Andersen, 2006, Bind 1:310) [S]

[7] Og de tog hinanden i hænderne og vandrede ud af det store slot. (Andersen, 2005:292)

Dzieci wzięły się za ręce i wyszły z okropnego pałacu. (Andersen, 1908:15) [N]

A oni wzięli się za ręce $\mathrm{i}$ wywędrowali $\mathrm{z}$ wielkiego pałacu (...) (Andersen, 1975, Bind $1: 182)[\mathrm{B} / \mathrm{I}]$

Dzieci wzięły się za ręce i opuściły wielki zamek (...) (Andersen, 2006, Bind 1:324) [S]

[8] (...) der står en dejlig pige; hun bøjer sig ud over rækværket og ser ned ad vejen. (Andersen, 2005:276)

(...) Stoi tam śliczna dziewczyna, wychyla się poza sztachety i patrzy na drogę. (Andersen, 1975, Bind 1:172) [B/l]

Stoi tam śliczna dziewczyna, przechyla się nad poręczą i patrzy w dół na drogę. (Andersen, 2006, Bind 1: 309) [S]

Eksempler fra Den lille havfrue

[9] Derfor sneg hun sig ud af sin faders slot, og og mens alt derinde var sang og lystighed, sad hun bedrøvet i sin lille have. (Andersen, 2005:134)

Ale nie mogła już tańczyć, smutno jej się zrobiło. Wymknęła się z sali i pośpieszyła do swego ogródka. (Andersen, 1908:8) [N]

Dlatego też wymknęła się z zamku ojca i podczas gdy wszyscy śpiewali i bawili się, siedziała smutna w swoim małym ogródku. (Andersen, 1975, Bind 1:54) [B/I]

Dlatego wymknęła się z zamku ojca, i gdy tam panowały śpiew i zabawa, ona siedziała zasmucona w swoim ogródku. (Andersen, 2006, Bind 1:160) [S]

[10] Da svømmede den lille havfrue længere ud bag nogle høje stene (...) (Andersen, 2005:131) Syrena zostawiła księcia, a sama odpłynęła za skały nadbrzeżne (Andersen, 1908:6) [N] 
Wtedy syrena odpłynęła znowu dalej, za wysokie kamienie wystające z wody (...) (Andersen, 1975, Bind 1:51) [B/I]

Wtedy syrenka odpłynęla nieco dalej za wystające z wody wysokie kamienie (...) (Andersen, 2006, Bind 1:157) [S]

[11] (...) kniven sitrede i havfruens hånd, - men da kastede hun den langt ud i bølgerne (...) (Andersen, 2005:142)

Nie! - odrzuciła zabójcze narzędzie precz, daleko, na fale, a gdzie stal ostra uderzyła wodę krew wytrysnęła kroplami wysoko. (Andersen, 1908:13) [N]

(...) nóż zadrżał w ręku syreny, odrzuciła go daleko w fale (...) (Andersen, 1975, Bind 1:60) $[\mathrm{B} / \mathrm{I}]$

(...) nóż zadrżał w dłoni syrenki - ale wtedy rzuciła go daleko w fale (...) (Andersen, 2006, Bind 1:170) [S]

[12] Hele den lange dag kunne de lege nede i slottet, i de store sale, hvor levende blomster voksede ud af væggene. (Andersen, 2005:126)

Przez cały dzień syreny igrały wesoło w koralowych salach ojcowskiego zamku, których ściany okrywały żywe kwiaty. (Andersen, 1908:2) [N]

Przez cały długi dzień dzieci mogły się bawić na dole w zamku, gdzie żywe kwiaty wyrastały wszędzie ze ścian. (Andersen, 1975, Bind 1:48) [B/I]

Całymi dniami mogły księżniczki bawić się w zamku, w wielkich salach, gdzie ze ścian wyrastały żywe kwiaty. (Andersen, 2006, Bind 1:150) [S]

[13] Hjemme på prinsens slot, når om natten de andre sov, gik hun ud på den brede marmortrappe (...) (Andersen, 2005:139)

Za to gdy noc nadeszła i wszyscy zasnęli w zamku królewskim, ona wstawała cichutko z purpurowej poduszki i biegła nad morze. Tu siadywała smutna na szerokich schodach i zanurzała w chłodnej morskiej wodzie nogi palące ją niby dwie rany. (Andersen, 1908:10) [N] Dopiero nocą w pałacu księcia, kiedy inni spali, wychodziła na szerokie marmurowe schody (...) (Andersen, 1975, Bind 1:58) [B/I]

Nocą, kiedy na zamku księcia wszyscy spali, wychodziła na szerokie marmurowe schody (...) (Andersen, 2006, Bind 1:165) [S]

\section{Eksempler fra Tommelise}

[14] Den gamle skrubtudse sad nede i mudderet og pyntede sin stue op med siv og gule åknappe, - der skulle være rigtig net for den nye svigerdatter, - svømmede så med den stygge søn ud til bladet, hvor Tommelise stod (...) (Andersen, 2005:95-96)

A ropucha tymczasem urządzała w głębi błota mieszkanie dla młodej pary. Przyozdobiła ciemną i szkaradną jamkę trzciną i wodnymi roślinami, ażeby się synowej podobała, popłynęła wraz z synem do listka, aby przenieść kolebkę panny młodej. (Andersen, 1908:3) $[\mathrm{N}]$

Stara ropucha (...) podpłynęła razem ze swoim wstrętnym synem do liścia, na którym stała Calineczka. (Andersen, 1975, Bind 1:29) [B/I]

Stara ropucha (...) popłynęla ze swoim brzydkim synem do liścia, na którym siedziała Calineczka. (Andersen, 2006, Bind 1:110) [S]

[15] (...) det blad, som var længst ude, var også det allerstørste; der svømmede den gamle skrubtudse ud og satte valnøddeskallen med Tommelise. (Andersen, 2005:95)

Po powierzchni strumienia pływały zielone, okrągłe liście wodnych lilii. Ropucha wybrała największy, który zarazem leżał najdalej od brzegu, i na nim umieściła łupinę orzecha ze śpiącą Calineczką.(Andersen, 1908:2) [N] 
Liść leżący najdalej był największy, do niego podpłynęła ropucha i postawiła na nim łupinę orzecha z Calineczką. (Andersen, 1975, Bind 1:29) [B/I]

(...) największy liść leżał najdalej. Do niego podpłynęła ropucha i położyła na nim skorupkę orzecha z Calineczką. (Andersen, 2006, Bind 1:110) [S]

[16] Hver morgen, når solen stod op, og hver aften, når den gik ned, listede hun sig ud i døren (...) (Andersen, 2005:101)

Co dzień o wschodzie i zachodzie słońca stawała przed norką myszy i z tęsknotą patrzała w górę, gdzie szumiały kłosy, jak las gęstego zboża. (Andersen, 1908:6)

Co rano, kiedy słońce wschodziło, i co wieczór, kiedy zachodziło, wymykała się za drzwi (...) (Andersen, 1975, Bind 1:34) [B/I]

Każdego ranka, kiedy wstawało słońce, i co wieczór, kiedy zachodziło, wymykała się do drzwi (...) (Andersen, 2006, Bind 1:115) [S]

[17] Tommelise var så bedrøvet. Hun fik slet ikke lov at komme ud i det varme solskin (...) (Andersen, 2005:101)

Smutno teraz było maleńkiej. Mysz jej nie pozwalała oddalać się z norki, a dokoła rosło zboże takie gęste i wysokie, że dla Calineczki stanowiło las prawdziwy, w którym nie widać jasnego słoneczka. (Andersen, 1908:6) [N]

Ale Calineczka była bardzo smutna. Nie mogła wyjść na ciepłe słońce. (Andersen, 1975, Bind 1:34) $[\mathrm{B} / \mathrm{I}]$

Calineczce było bardzo smutno. Nie wolno jej było w ogóle wychodzić na ciepłe słonko (...) (Andersen, 2006, Bind 1:115) [S]

[18] Farvel, farvel! Du gode, nydelige pige! sagde svalen og fløj ud i solskinnet. (Andersen, 2005:101)

- Więc bądź zdrowa, kochana, dobra Calineczko! - zaszczebiotała wesoło jaskółka i przez słoneczny otwór wzleciała ku górze i zniknęła w ciepłym blasku. (Andersen, 1908:5) [N]

- Bądź zdrowa, moja dobra, śliczna dziewczynko! - pożegnała ją jaskółka i poleciała ku słońcu. (Andersen, 1975, Bind 1:34) [B/I]

- Żegnaj, żegnaj, ty dobra, miła panienko! - zawołała jaskółka i pofrunęła ku słonecznemu światłu. (Andersen, 2006, Bind 1:115) [S]

Eksempler fra Den lille Idas blomster

[19] (...) kommer da professoren ud i haven, så er der ikke en eneste blomst, og han kan slet ikke forstå, hvor de er henne (...) (Andersen, 2005:89)

Pan profesor przychodzi sobie do ogrodu, a tu nie ma ani jednego kwiatka! (Andersen, 1908:3) [N]

(...) Profesor przyjdzie do ogrodu i nie zastanie tam ani jednego kwiatka; nie będzie mógł zrozumieć, gdzie się podziały. (Andersen, 1975, Bind 1:23) [B/I]

A jak profesor przyjdzie do ogrodu, to nie będzie tam ani jednego kwiatka, i nie będzie mógł zrozumieć, gdzie się podziały. (Andersen, 2006, Bind 1:99) [S]

[20] (...) hun krøb ud af sin lille seng og gik ganske sagte hen til døren og kiggede ind i stuen. (Andersen, 2005:90)

Na koniec Ida dłużej wytrzymać nie mogła. Wyszła pomalutku z łóżka i na palcach podeszła do drzwi uchylonych. (Andersen, 1908:4) [N]

(...) Dziewczynka (...) wysunęla się z łóżeczka, wyśliznęła się cichutko za drzwi i zajrzała do drugiego pokoiku. (Andersen, 1975, Bind 1:26) [B/I]

(...) Ida (...) wysunęła się ze swojego łóżeczka, cichutko podeszła do drzwi i zajrzała do salonu. (Andersen, 2006, Bind 1:102) [S] 
[21] (...) røgmanden løb hen til kanten af bordet, lagde sig langs ud på sin mave og fik skuffen en lille smule trukket ud. (Andersen, 2005:91)

Kominiarczyk natychmiast pośpieszył na brzeg stolika, położył się na brzuchu i z całej siły zaczął wyciągać szufladkę. (Andersen, 1908:4) [N]

Kominiarczyk wybiegł na brzeg stołu, położył się na brzuchu i udało mu się trochę wysunąć szufladę. (Andersen, 1975, Bind 1:27) [B/I]

Dziadek do orzechów pobiegł na brzeg stołu, położył się na brzuchu jak długi i nieco wysunął szufladę. (Andersen, 2006, Bind 1:103) [S]

Eksempler fra Rejsekammeraten

[22] Johannes var nu kommet ud af skoven, da en stærk mandsstemme råbte bagved ham (...) (Andersen, 2005:111)

Janek wyszedł z lasu i szedł teraz drogą, kiedy usłyszał za sobą wołanie (...) (Andersen, 1908:4) $[\mathrm{N}]$

Jan wyszedł właśnie z lasu, kiedy usłyszał, że jakiś donośny, męski głos woła za nim. (Andersen, 1975, Bind 1:40) [B/I]

Johannes wyszedł już z lasu, gdy usłyszał silny męski głos. (Andersen, 2006, Bind 1:124) [S]

[23] (...) så førte han Johannes ud i prinsessens lysthave, der så forskrækkeligt ud! (Andersen, 2005:115)

I zaprowadził Janka do ogrodu królewny. Okropny widok! (Andersen, 1908:7) [N]

I zaprowadził Jana do ogrodu księżniczki, i pokazał mu straszny widok. (Andersen, 1975, Bind $1: 43)[\mathrm{B} / \mathrm{I}]$

I zaprowadził Johannesa do ogrodu królewny, a tam było strasznie! (Andersen, 2006, Bind 1:129) [S]

[24] Johannes gav ham de sølvskillinger han havde og gik så lykkelig og fornøjet længere frem, ud i den vide verden. (Andersen, 2005:109)

Wychodząc z cmentarza, dał ubogiemu kilka sztuk monet i poszedł dalej. (Andersen, 1908:3) $[\mathrm{N}]$

Jan dał mu wszystkie srebrne pieniądze, jakie miał, i poszedł zadowolony i szczęśliwy w daleki świat. (Andersen, 1975, Bind 1:39) [B/I]

Johannes dał mu srebrne szylingi, i szczęśliwy i zadowolony poszedł dalej w szeroki świat. (Andersen, 2006, Bind 1:123) [S]

[25] Da Johannes sov, fløj rejsekammeraten efter prinsessen ud til bjerget (...) (Andersen, 2005:120)

Gdy Janek zasnął, towarzysz podróży poleciał na skrzydłach łabędzia za księżniczką do czarownika (Andersen, 1908:9) [N]

Kiedy Jan zasnął, jego towarzysz poleciał za księżniczką na górę (...) (Andersen, 1975, Bind $1: 45)[\mathrm{B} / \mathrm{I}]$

Gdy Johannes spał, towarzysz podróży poleciał za królewną na górę (...) (Andersen, 2006, Bind 1:132) [S]

[26] Tidlig næste morgen pakkede Johannes sin lille bylt sammen, gemte i sit bælte hele sin arvepart, der var 50 rigsdaler og et par sølvskillinger, dermed ville han vandre ud i verden. (Andersen, 2005:108)

Nazajutrz wczesnym rankiem Janek zwinął w mały tobołek swoje rzeczy, zabrał pięćdziesiąt talarów i kilka drobnych monet, które stanowiły cały jego majątek i wyruszył w drogę. (Andersen, 1908:2) [N]

Nazajutrz wczesnym rankiem spakował Jan mały węzełek i schował do sakiewki za pasem cały odziedziczony po ojcu majątek, składający się z pięćdziesięciu talarów i paru srebrnych szylingów; z tym chciał ruszyć w świat. (Andersen, 1975, Bind 1:38) [B/I] 
Następnego dnia wcześnie rano Johannes spakował niewielki tobołek, ukrył w pasku cały swój majątek, a było tego pięćdziesiąt talarów i kilka srebrnych szylingów, i z tym postanowił wyruszyć w świat. (Andersen, 2006, Bind 1:122) [S]

[27] I det samme kom prinsessen selv, med alle sine damer, ridende ind i slotsgården, de gik derfor ud til hende, og sagde god dag. (Andersen, 2005:116)

Właśnie na dziedziniec zamkowy wjechała piękna królewna ze swymi damami, więc pośpieszyli, aby ją powitać. (Andersen, 1908:7) [N]

Wkrótce księżniczka razem ze swoimi wszystkimi damami dworu wjechała na podwórze zamkowe; wyszli więc do niej i przywitali się. (Andersen, 1975, Bind 1:43) [B/I]

W tej samej chwili na zamkowe podwórze wjechała konno królewna we własnej osobie, z wszystkimi swoimi damami. Johannes i król wyszli do niej się przywitać. (Andersen, 2006, Bind $1: 129)[\mathrm{S}]$

[28] (...) kroppen kastede han ud i søen til fiskene. (Andersen, 2005:121)

Szkaradny tułów rzucił potem w głąb jeziora rybom na pożarcie (...) (Andersen, 1908:10) $[\mathrm{N}]$

(...) Ciało rzucił do jeziora na pożarcie rybom (...) (Andersen, 1975, Bind 1:46) [B/I]

Ciało towarzysz podróży rzucił rybom w morzu (...) (Andersen, 2006, Bind 1:134) [S]

[29] Endelig kom hun da ud til bjerget og bankede på. (Andersen, 2005:118)

Na koniec dopłynęła do ogromnej góry i zapukała trzy razy. (Andersen, 1908:8) [N]

Wreszcie przyleciała ku górze i zapukała. (Andersen, 1975, Bind 1:44) [B/I]

W końcu doleciała jednak do góry i zapukała. (Andersen, 2006, Bind 1:130-131) [S]

Eksempler fra Den grimme alling

[30] "Pip! Pip!" sagde ungen og væltede ud; han var så stor og styg. (Andersen, 2005:252)

" - Pip, pip! -" odezwało się pisklę i prędko wydostawać się zaczęło ze skorupki. Było bardzo duże

i brzydkie! (Andersen, 1908:3) [N]

"Pip, pip!" - zapiszczało pisklątko i wylazło; było bardzo duże i brzydkie. (Andersen, 1975, Bind $1: 154)[\mathrm{B} / \mathrm{I}]$

"Pip! pip!" - pisnęło maleństwo i wykaraskało się ze skorupki; było duże i brzydkie. (Andersen, 2006, Bind 1:281) [S]

[31] Børnene ville lege med den, men ællingen troede, at de ville gøre den fortræd, og for, i forskrækkelse, lige op i mælkefadet, så at mælken skvulpede ud i stuen. (Andersen, 2005:257) Kaczę w cieple przyszło do siebie i dzieci zaraz chciały się z nim bawić; ale ono myślało, że mu chcą zrobić co złego i zaczęło uciekać, przewróciło garnek z mlekiem i rozlało je na podłogę. (Andersen, 1908:6) [N]

Dzieci chciały się z nim bawić, ale kaczątko myślało, że chcą mu zrobić coś złego, i ze strachu wpadło do miski z mlekiem, tak, że mleko rozlało się po izbie. (Andersen, 1975, Bind 1:158) $[\mathrm{B} / \mathrm{I}]$

Dzieci chciały się z nim bawić, ale kaczątko myślało, że chcą mu zrobić krzywdę, zerwało się przerażone i wpadło wprost do miski $\mathrm{z}$ mlekiem; mleko rozlało się po izbie (...) (Andersen, 2006, Bind 1:286) [S]

[32] (...) det var svaner, de udstødte en ganske forunderlig lyd, bredte deres prægtige, lange vinger ud og fløj bort fra de kolde egne til varmere lande (...) (Andersen, 2005:257)

Były to odlatujące łabędzie. Nagle wydały ton długi, przeciągły, tak dziwny! Poruszyły spokojnie silnymi skrzydłami i wzniosły się wysoko, aż pod chmury i płynęły tak dalej, dalej, w nieskończoność. (Andersen, 1908:6) [N] 
(...) były to łabędzie. Wydawały dziwne dźwięki, rozpostarły wspaniałe, długie skrzydła i odleciały z zimnych okolic do ciepłych krajów (...)" (Andersen, 1975, Bind 1:157) [B/I] (...) były to łabędzie. Wydały $\mathrm{z}$ siebie niezwykłe dźwięki, rozpostarły wspaniałe, długie skrzydła i odleciały z tej zimnej krainy do cieplejszych krajów (...) (Andersen, 2006, Bind $1: 285)[\mathrm{S}]$

[33] Og den fløj ud i vandet og svømmede hen imod de prægtige svaner (...) (Andersen, 2005:258)

I tak popłynęło naprzeciw łabędzi, które, ujrzawszy przybysza, potężnie zaszumiały skrzydłami i skierowały się prosto ku niemu. (Andersen, 1908:7) [N]

Sfrunęło na wodę i zaczęło płynąć ku wspaniałym łabędziom. (Andersen, 1975, Bind 1:158) $[\mathrm{B} / \mathrm{I}]$

I sfrunęło na wodę i popłynęło ku wspaniałym łabędziom (...) (Andersen, 2006, Bind 1:287) [S]

[34] Jeg tror, jeg vil gå ud i den vide verden! sagde ællingen (...) (Andersen, 2005:257)

- Pójdę sobie w świat chyba - rzekło kaczę. (Andersen, 1908:6) [N]

- Myślę, że pójdę sobie w świat! - Powiedziało kaczątko (Andersen, 1975, Bind 1:157) [B/I]

- Chyba pójdę sobie w świat! - Powiedziało kaczątko (Andersen, 2006, Bind 1:285) [S]

[35] I haven kom der nogle små børn, de kastede brød og korn ud i vandet (...) (Andersen, 2005:258)

Kilkoro dzieci wbiegło do ogrodu i zaczęło z brzegu rzucać w wodę bułki i smaczne ziarnka. (Andersen, 1908:7) [N]

Do ogrodu przyszło kilkoro małych dzieci, które rzucały chleb i ziarnka do wody (...) (Andersen, 1975, Bind 1:158) [B/I]

Do ogrodu przyszło kilkoro małych dzieci, rzucały do wody chleb i ziarno (...) (Andersen, 2006, Bind 1:287) [S]

\section{Michał Smułczyński}

Uniwersytet Wrocławski

Instytut Filologii Germanńskiej

pl. Nankiera $15 b$

50-140 Wrocław

Poland

michal.smulczynski@uwr.edu.pl 